\title{
INTERNATIONALISATION AND AFRICAN INTELLECTUAL \\ METISSAGE: CAPACITY-ENHANCEMENT THROUGH HIGHER EDUCATION IN AFRICA
}

\author{
C. C. A. Hagenmeier*
}

Director of International Relations

e-mail: cornelius.hagenmeier@univen.ac.za

\author{
A. Lansink* \\ Dean of Law \\ e-mail: annette.lansink@univen.ac.za
}

*University of Venda

Thohoyandou, South Africa

\section{G. N. K. Vukor-Quarshie}

Professor of Law

MountCrest University

Accra, Ghana

e-mail: novisibball@yahoo.com

\section{ABSTRACT}

This article seeks to contribute to the discourse on the appropriate African response to globalisation and internationalisation in higher education by examining the role of internationalisation in capacity-enhancement and development in Africa. In the first part, it explores the theoretical underpinnings of capacity-enhancement through university education and analyses how the intertwined processes of internationalisation and Africanisation can contribute to capacity-enhancement and development in Africa. It is argued that the concept of intellectual metissage, as a form of intellectual cross-fertilisation across international borders, is a necessary and appropriate tool to drive internationalisation with the aim of fulfilling the developmental mandate of African universities. In the second part, a prestigious and highly successful international partnership programme, the LLM/MPhil in human rights and democratisation in Africa is analysed to determine its suitability to drive and actualise the capacity-enhancement aspect of higher education in Africa through intellectual métissage.

Keywords: globlisation, internationalisation, Africanisation, capacity-enhancement, development, legal education, democratisation, human rights 


\section{INTRODUCTION}

In the past few decades, there has been an intense debate on the appropriate African response to globalisation and internationalisation in higher education (Olukoshi and Zelelza 2004; Cross and Rouhani 2004). This article seeks to contribute to this discourse by examining the role of internationalisation for capacity-development in Africa. In the first part, it explores theoretical underpinnings and analyses how the intertwined processes of internationalisation and Africanisation can contribute to the project. In this article, Africanisation is used to mean that the higher education system should be informed by the shared knowledge, values, experiences, aspirations, and economic objectives of Africans (Makgoba and Seepe 2004; Lebakeng 2004). We argue that an Africa-focused and imbued internationalisation process would greatly assist Pan-African capacity-enhancement objectives and contribute to the continent's development. In this context we apply the term metissage to denote the process of intellectual crossfertilisation across international borders on the continent.

It is our view that the concept of African intellectual métissage is a necessary tool to transform and advance internationalisation in African higher education, so as to achieve the developmental mandate of African universities. The second part focuses on and analyses the application of principles of African intellectual metissage to the management of the Master's level international programme offered by the Centre for Human Rights at the University of Pretoria. This is a programme offered in partnership with thirteen other African universities from across the continent, namely, the LLM in Human Rights and Democratisation in Africa (HRDA).

\section{INTERNATIONALISATION OF AFRICAN HIGHER EDUCATION}

Generally, internationalisation is understood as the 'process of integrating an international, intercultural, or global dimension into the purpose, function or delivery of post-secondary education’ (Knight 2004, 9). As a result of colonialism, African universities have developed with a specific but rather narrow international outlook. In concordance with the continent's colonial history, most African states developed tertiary education structures which were inspired by those of their respective colonial masters, and worked with partners in the relevant former colonial countries. After independence, this focus did not shift fundamentally.

Higher education in Africa is currently in the process of casting off its colonial moorings and embracing internationalisation in the true sense of the word. African universities have therefore set sail towards a brave new vision characterised by setting the internationalisation agenda that is founded in globally accepted and theoretically-based principles (Jooste 2012). 
As African universities embark on the journey to developing practices that can become the foundation for long-term sustainability of internationalisation, they need to develop and adopt new practices to face the $21^{\text {st }}$ century's challenges (Jooste 2012). The question which consequently arises is: What should be the future foundations of internationalisation in Africa? One possible approach would be to continue on the mainstream trajectory; however, there is a counter argument that the African higher education response to globalisation should be different. Provocatively, De Wit has posed the question whether there is a necessity to deinternationalise African Higher Education to overcome Western hegemony (Jowi, Knight and Sehoole 2013). While 'de-internationalising' would be fallacious, it is important that a particular African process for internationalisation be developed, fully reflective of the African identity. It is impossible to sustain internationalisation processes if they are not based on a sound sense of identity and cultural foundation.

In line with the Pan-African ideal, which emphasises the common destiny shared by African people, African universities should embrace the interconnectedness and interdependency of social and economic development. In this respect, African universities should promote Pan-Africanism as well as international programmes. Higher education in the $21^{\text {st }}$ century will have to transcend national borders and focus on regional and international elements. In essence, we advocate that the blueprint of $21^{\text {st }}$ century higher education in Africa must be imbued with vital and durable elements of capacity-enhancement and internationalisation. The internationalisation programme should be an African intellectual agenda which emphasises African roots and identities, an African intellectual metissage ${ }^{1}$ where educational capacity-enhancement programmes are designed for 'African' rather than, for example, ‘Nigerian’ or 'South African’ national conditions.

In further exploring the concept of African intellectual metissage we must confess immediately that numerous attempts have been made in the course of African political history to erect a common and broad edifice of 'Africanism'. Echoes of such broad 'African' agenda can be found in the philosophical construct of Negritude, a literary and ideological movement spawned by a group of black francophone intellectuals and writers in France in the 1920s and 1930s. One of the leading lights in this movement was the man who would become the future President of Senegal, Leopold Sedar Senghor. ${ }^{2}$ Negritude was an ideological movement advocating a common black identity and solidarity as a bulwark against French colonialism. Another famous champion of 'Africanism' was Dr Kwame Nkrumah, the first president of the Republic of Ghana. His central and consistent theme contained in works such as Africa Must Unite (Nkrumah 1963), Neo Colonialism: The Last Stage of Imperialism (Nkrumah 1965) and 
Consciencism (Nkrumah 1964) is that for prosperity and true freedom from colonialism, African countries must unite at the economic, political and defence fronts.

Our call for African intellectual metissage is not one for a political or economic African unity; ours is a call for insulating African tertiary education from narrow national particularism. It is a call for the cross-fertilisation of African tertiary education to promote and spawn a new breed of African scholar who would drive and sustain a broad range of African programmes a scholar who would be able to execute the African Union's agenda at multiple locations, such as at its headquarters in Addis Ababa, Ethiopia, or at the African Commission on Human and Peoples' Rights in Banjul, Gambia, or at the New Partnership for African Development (NEPAD) headquarters in Midrand, South Africa, or at the ECOWAS Court of Justice, Abuja, Nigeria. Such a person would be a finished product of tertiary education imbued with African intellectual metissage.

\section{CAPACITY-ENHANCEMENT IN AFRICA: THE RATIONALE}

It is axiomatic that higher education in Africa needs to be strengthened and transformed in order to address the legacy of its colonial past. A similar sentiment was echoed in the foreword to the South African White Paper on Higher Education: Programme for the Transformation of Higher Education (1997, 3), by the then Minister of Education, Prof SME Bengu, who had observed that;

The higher education system must be transformed to redress past inequalities, to serve a new social order, to meet pressing national needs and to respond to new realities and opportunities ....

It is relevant at this point to note that way back in 1973, Tijani Yesufu had argued that,

... the emergent African university must ... be much more than an institution for teaching, research and dissemination of higher learning. It must be accountable to, and serve, the vast majority of the African people who live in rural areas. The African university must be committed to active participation in social transformation, economic modernization, and the training and upgrading of the total human resources of the nation, not just a small elite (Yesufu 1973).

This means that in addition to the generally recognised purposes of a university, African universities should position themselves as catalysts for regional development. In other words, African universities should vigorously and purposively champion and undertake capacityenhancement for the entire region as the rationale for their internationalisation and Africanisation efforts. We advocate in this article that capacity-enhancement for the development of the entire African continent should be the fulcrum of the African 
internationalisation agenda and strategies. African universities should promote Pan-Africanism as well as international programmes and respond to the developmental needs of the continent. Higher education in the $21^{\text {st }}$ century will have to transcend national borders and focus on regional and international elements.

Our argument is that African intellectual métissage demands a paradigm shift in higher education so as to respond to the specific and peculiar needs of the African continent as well as the broader overarching dictates of internationalisation. At this point, we cannot resist the temptation to once again quote the apposite and congruous thesis of Yesufu that to achieve these stated goals, it is necessary to formulate a new philosophy of university education,

in the hope of evolving institutions that are not only built and sited in Africa, but are of Africa, drawing inspiration from Africa, and are eloquently dedicated to her ideals and aspirations (Yesufu 1973).

Given the vital link between higher education and development, any strategy intended to achieve this must include plans and policies on the role of higher education in skills development. Any long-term development plan requires that the state and government design means and methods to capacitate its people for participation in the economy. It was for this reason that the post-independence public university in Africa was conceived as ontologically embedded in the developmental state with its recognition of the need for socio-economic development (Lumumba 2008).

A similar argument has been advanced by the 1998 World Declaration on Higher Education for the $21^{\text {st }}$ century:

Without adequate higher education and research institutions providing a critical mass of skilled and educated people, no country can ensure genuine endogenous and sustainable development and, in particular, developing countries and least developed countries cannot reduce the gap separating them from the industrially developed ones (World Conference on Higher Education 1998).

The higher education sector is primarily responsible for delivering the capacity necessary to build the labour market and economy. It is tasked with creating knowledge and enhancing skills, abilities and competencies necessary for society. Higher education enables intellectual development and equips individuals with organisational skills and training that enable efficient and effective performance. This seems a truism and a foregone conclusion to us now, but the idea was not always supported by all organisations and governments. Less than two decades ago, the World Bank recommended that countries in Africa invest rather in primary and secondary education than in higher education (World Bank 1999) because of the allegedly low 
return on investment in university education in Africa. Subsequently, funding for higher education and consequently the development of professional skills in Africa declined.

Significantly, in recent years, the World Bank has moved away from 'its anti-university orientation' of the 1990s and recognised the important role of higher education in development (Olukoshi and Zeleza 2004; Cross and Rouhani 2004). This newly found wisdom is echoed in pronouncements and publications of the United Nations Development Programme's (UNDP) 2008-2013 Strategic Plan for Development, which emphasises capacity-enhancement through making greater investments in education systems and creating opportunities for learning and developing professional skills (World Health Organization 2013).

The argument developed in this article is that a major intervention strategy to counter the human-resource gap in Africa can be regarded as cross-border capacity-enhancement within the continent. Given our preference for self-reliance we envisage that this task of empowerment falls in the first place on the shoulders of African governments and institutions of higher learning.

\section{STRENGTHENING THE SYSTEM OF HIGHER EDUCATION TO RESPOND TO THE DEVELOPMENTAL NEEDS OF AFRICA}

In order to support capacity-enhancement in Africa, it is necessary to develop suitable interventions and programmes which may include the following pillars:

\section{Curricula and programmes designed for African needs}

To achieve the desideratum of strengthening the higher education system to respond to African developmental needs, our first recommendation is that African higher education institutional curricula and programmes be designed to respond to African human resource needs and challenges. In Africa, the notion of the internationalisation of the curriculum has been widely accepted. It has been defined by the OECD as

a curriculum with an international orientation in content and/or form, aimed at preparing students for performing (professionally/socially) in an international and multicultural context and designed for domestic and/or foreign students (OECD1996).

While internationalisation of the curriculum will make an important contribution to capacityenhancement, curricula interventions in Africa should not be limited to the infusion of international and intercultural elements into teaching. Rather, it is necessary to additionally enhance local relevance and focus on content which will respond to the specific human capacity needs of the continent. 
Another critical aspect is that curricula and programmes must equip students to fully understand the context of the African continent. In this vein, they should include a strong focus on African indigenous knowledge systems and languages. Similarly, it is essential for the development of an African worldview that the students are imbued with an understanding of African needs, interests and cultures in the broadest possible sense and this needs to be fostered through relevant curricula (Ramose 1999; Makgoba and Seepe 2004; Lansink 2004).

The primary aim of the discourse on Africanisation is to support the needs, interests and aspirations of people living on the African continent. The focus is on raising the awareness of students regarding the special and peculiar needs of their own societies, while simultaneously preparing those students for global citizenship. We shall call the process of creating continental and global awareness 'dynamic symbiosis' - a process which will be running concurrently, infusing and buttressing each other.

We reiterate that for curricula to be locally, continentally and internationally relevant, transformation of the curricula is required. The research, teaching and learning agenda should be determined by both the national and continental demands and should serve the special interests of African people.

\section{International partnerships for capacity-development}

We argue secondly that strengthening the higher education system to respond to African developmental needs advances the vision of true and proper international partnerships for capacity-enhancement. International partnerships between universities on the continent can assist in capacity-enhancement as often expertise which is available in one university is lacking in another university. In such situations, pooling and sharing of resources by partner universities can assist in establishing leadership and management as well as academic capacity. For example, African universities are often not in a position to adequately respond alone to the Millennium Development Goals (Jowi, Knight and Seehoole 2013), but when capacity is enhanced through continental partnerships, universities can together make significant contributions to the attainments of the goals. Many international partnerships involving African universities have been established with Euro-American counterparts, and some of them are not truly 'partnerships'. This is due primarily to the gross and sometimes obscene disparity in the financial resources of the partners. Our vision of true and proper international partnerships for capacity-enhancement are partnerships in which all the parties are truly equal, and which are anchored in ethical principles (Hagenmeier 2015). The scope of this article does not allow us to unpack this aspect completely; suffice to say that we agree with the call of the Nelson 
Mandela Bay Declaration on the future of internationalisation that 'a set of international partnership guidelines shall be developed and proposed ... to ensure equal and ethical practices in international education' (Global Dialogue 2014). While this global effort is advancing, African higher education institutions should continue to develop partnerships in other world regions whilst firmly invoking their rights as equal partners in them, and additionally focus on ethical and equal continental higher education partnerships.

\section{Funding}

Our third contention for strengthening the African higher education system to respond to African developmental needs dwells on funding sources. Availability of funding for higher education is paramount to capacity-development. African stakeholders should increasingly focus on developing collaborative funding sources. It is essential that African stakeholders catalyse the laudable donor efforts to make them subject to local, regional and continental needs as identified by the African partners.

Governments should be encouraged to commit financially to capacity development in the entire African region, as exemplified by South Africa's commitment to subsidising SADC fulldegree students in the country. African universities should refrain from charging high international fees for students from the African continent, which result in the exclusion of aspiring youth from lower-income countries from studying in other African nations. For example, at many South African universities ${ }^{3}$ international fees are charged for non-SADC students. Laudably, Article 7(A) (5) of the 1997 SADC Protocol on Education and Training provides that Member States agree that they 'shall treat students from SADC countries as home students for purposes of fees and accommodation' (SADC 1997). Scholarship programmes should provide for capacity-development needs of Africa, and should not be limited to recipients of one nationality. Governments should be encouraged to promote this notion in their negotiations with external donors.

Furthermore, governments and universities should create enabling financial structures, funding grids and administrative environments that go with the unique demands of joint programmes across Africa as these programmes often do not fit into standard university categories in terms of funding and administration (Heyns 2006). New funding categories for African capacity-enhancement mobility schemes, including intra-African student exchanges and joint degree programmes, need to be included in African governmental higher education frameworks to provide the necessary resources for capacity-enhancement through African intellectual metissage. 
We additionally advance the view that the role of African intergovernmental and international organisations, for example, the African Commission, should be purposively enhanced to act as catalysts for strengthening the higher education system to respond to African developmental needs. The 'New Economic Partnership for Africa's Development (NEPAD)', a programme developed by the African Union, provides an integrated strategic framework for socio-economic development in Africa. It includes a focus on higher education and capacity development (NEPAD 2009) while particularly promoting the establishment of regional centres of excellence, which are conceptualised as Pan-African institutions. Capacity-enhancement through university education is seminal to the achievement of NEPAD's vision. The African Union has committed itself in the 2007 Addis Ababa Declaration on Science and Technology to 'ensure the enhanced role and the revitalisation of African universities and other African institutions' (African Union 2007). This philosophy was put into practice with the establishment of the Pan-African University in 2011, with four institutes in four regions (North, Central, West and East), and the possible addition of the Southern African region (African Union 2011). In addition, voluntary organisations of universities such as the Southern African Regional Universities Association (SARUA) and the African Association of Universities (AAU) play and important role and should be strengthened

\section{Continental and regional integration of higher education}

Our next argument for the strengthening of the higher education system in order to respond to African developmental needs expands on the concept of continental and regional integration of higher education. In this context, due consideration must be given to continental and regional integration akin to the Bologna process. Continental credit transferability, programme accreditation and/or recognition, system articulation across national borders should enable graduates to pursue further studies at universities in other parts of the continent. This will be of relevance in particular when joint degrees are being offered transnationally.

For the Southern African Region, the 1997 SADC Protocol on Education and Training (SADC 1997) provides a framework for co-operation in higher education in the SADC region. It obliges signatories to reserve at least 5 per cent of admission for students from the SADC region to work toward harmonisation, equivalence and eventual standardisation of university entrance requirement and the development of credit transfer mechanisms (SADC 1997). The Protocol promotes the pooling of resources for the development of high-quality postgraduate programmes and the establishment of regional centres of specialisation. We consider the implementation of this laudable agenda as urgent not only for Southern Africa's higher education system, but for the entire African continent. 


\section{CASE STUDY: MASTERS IN HUMAN RIGHTS AND DEMOCRATISATION IN AFRICA (HRDA)}

We selected this specific Master's programme ${ }^{4}$ for this study because it is our hypothesis that it may be an excellent example of a capacity-enhancement postgraduate study programme in Africa which is realising African intellectual métissage. The LLM/MPhil programme is presented by the Centre for Human Rights at the University of Pretoria in South Africa in conjunction with thirteen other faculties of law at universities in Africa. ${ }^{5}$ The University of Venda is a partner in this programme. ${ }^{6}$ Consequently, the researchers had access to relevant strategic and operational documentation. ${ }^{7}$

The analysis of the structure and delivery is amplified through an integrated high-level comparison with two European human rights Masters programmes; namely the European Master's Degree in Human Rights and Democratisation (E.MA) and the European Regional Master's Degree in Human Rights and Democratisation for South Eastern Europe (ERMA). The purpose of the comparison is to provide a context to the origin and status of the programme which will also allow conclusions to be drawn regarding its feasibility and impact on internationalisation and capacity-enhancement.

A sample of experiences from graduates of the programme has been collected. Furthermore, statistical information on present and past employment of the former students was obtained through the Centre for Human Rights at the University of Pretoria using complete alumni information. ${ }^{8}$ An additional survey was conducted to gain a deeper understanding of the impact of the programme on opportunities, employability and skills development.

\section{Background and purpose of the programme}

The HRDA was launched in 2000 as a Master of Laws Programme and is now a combined Master of Laws/Master of Philosophy in Human Rights and Democratisation in Africa Programme. HRDA is connected to other regional human rights master's programmes through the Global Campus, which was launched in 2012 through a Memorandum of Understanding between six regional master's programmes. It is spread over five continents and includes almost one hundred universities. ${ }^{9}$

By the end of 2014, 434 students (199 female and 235 male) from 43 countries from all African regions had graduated from this human rights programme, aimed at training human rights experts who would contribute to the promotion of human rights and democratisation on the African continent. Its overall objectives as stated in a recent funding proposal are, first, to 
ensure that Africa has human rights and democratisation experts to serve national, international, regional and governmental and non-governmental structures; second, to build capacity at the partners' faculties, expand the collaboration among them, as well as to further develop the relationship between the African Master's and the other regional human rights Master's programmes. ${ }^{10}$ Speaking about the programme, alumnus Horace Adjolohoun (Benin) (LLM graduate of 2007) points out that 'the ultimate goal is to bring about tangible change in leadership and human development in Africa' (University of Pretoria: Alumni Association 2012). Specifically, the programme aims 'to ensure transfer of technical skills and strengthen the capacity of these organisations with the goal of improving the protection and promotion of human rights and democratisation in Africa' (Centre for Human Rights (CHR)). Upon completion of the qualification, graduates should be employable in government ministries as well as in national, regional and international, inter-governmental organisations and NGOs advancing human rights and democratisation.

The programme also aims to build a network of human rights professionals in Africa to promote human rights scholarship which addresses the needs of Africa, expand collaboration between African universities and to strengthen links between civil society, governmental bodies and international organisations (CHR). The founding Director of the Centre for Human Rights, Christof Heyns, accentuates the role of good universities and law faculties as indispensable elements of development and progress in societies. It is thus not surprising that the promotion of the rule of law and values of social justice on the African continent is foregrounded in the networks and programmes offered by the Centre (Visser and Heyns 2007).

\section{Comparison with selected similar Masters programmes in Europe}

The African programme is modelled on the first regional programme of its kind in Europe, first offered by the University of Padua and now by the European Inter-University Centre of Human Rights and Democratisation (EIUC) in Venice in partnership with 41 other universities. The European Master's Programme in Human Rights and Democratisation (EMA) in human rights and democratisation relies on an extensive network 'to draw on first class lecturers from an allEuropean network and recruit students from all over Europe’ hence bringing together a rich variety of experiences (MEDE 2003). ${ }^{11}$ Another European Regional Master’s Programme in Human Rights and Democratisation for South Eastern Europe (ERMA) is based in Sarajevo, Bosnia-Herzegovina and co-managed by the University of Bologna, Italy. Other similar masters programmes in Human Rights and Democratisation are the master's in Human Rights and Democratisation in the Asia-Pacific region, coordinated by the University of Sydney, Australia; 
the Regional Master's Programme in Human Rights and Democratisation in the Caucasus, coordinated by Yerevan State University, Armenia; and the Master's in Human Rights and Democratisation in Latin American and the Caribbean, coordinated by the University of San Martin, Buenos Aires, Argentina. From 2015, a new multi-disciplinary master's programme is being offered: a Master in Democratic Governance - Human Rights and Democracy in the Middle East and North Africa (MENA region). This new and seventh regional master's programme has also be linked to the Global Campus (EIUC). For purposes of this article, however, only the HRDA, EMA and ERMA Master's Programmes have been analysed.

The common denominator of all three programmes (HRDA, EMA and ERMA) is that they aim at increasing capacity in human rights and democratisation. ${ }^{12}$ The three programmes however differ in some essential aspects such as partnership structure, programme design, format and delivery. The similarities and differences are highlighted for the purpose of describing different models of collaboration.

\section{Partnership structure}

Amongst the three, the HRDA is the only programme that caters for an entire continent. The programme was launched in 2000 and has successfully been offered since then, on average, to thirty students per year. The coordinating cum administrative institution/body is the Centre for Human Rights at the University of Pretoria, South Africa. The following universities are formal partners in the HRDA:

- $\quad$ Université d’Abomey-Calavi (Benin);

- $\quad$ Addis Ababa University (Ethiopia);

- $\quad$ University of Alexandria (Egypt)

- $\quad$ Catholic University of Central Africa (Cameroon);

- $\quad$ Universidade Eduardo Mondlane (Mozambique);

- $\quad$ Université Gaston Berger de Saint Louis (Senegal);

- $\quad$ University of Ghana (Ghana);

- $\quad$ University of Lagos (Nigeria)

- $\quad$ Makerere University (Uganda);

- University of Mauritius (Mauritius)

- University of Nairobi (Kenya)

- $\quad$ University of Venda (South Africa);

- $\quad$ University of the Western Cape (South Africa); 
By comparison, the EMA focuses only on those European countries which are EU member states. The EIUC is a unique inter-university centre that coordinates the EMA in which fortyone universities from all European Union Member States participate. The EIUC provides the institutional foundation and management to coordinate the EMA and additional human rights educational programmes. The EMA is the oldest of the programmes, having been established in 1997. It has been expanded to include many more universities in addition to the initial ten participating institutions.

The ERMA focuses only on one sub-region of Europe that is the post-conflict Balkan region. The ERMA is run by two leading research institutions affiliated with the University of Sarajevo and Bologna; eleven additional partner universities participate in the programme. The programme was started in 2001 with an intention to develop capacity in a post-conflict region aimed at democratisation and reconciliation of countries which had formally engaged in an armed conflict. This context therefore impacts on the curriculum design.

\section{Programme delivery}

Delivery of the HRDA is characterised by its interdisciplinary, action-and-policy oriented approach to human rights education. In the first semester, instruction is centralised, but students engage in one week community-engaged research visit at selected partner universities. In the second semester, students are placed at the various partner universities. From January to June, students enrol for modules which are taught at the coordinating Centre for Human Rights at the University of Pretoria.

During the second semester the LLM/MPhil candidates spend six months at one of the partner universities. They enrol for an academic module or participate in an internship programme and write their prescribed mini-dissertations under the supervision of academics of the partner university. The EMA is centrally delivered at the site of the EIUC during the first semester. The EMA is organised over one academic year which starts in September. Students are based in Venice, Italy, until January the following year. During the second semester, students are based at a partner university for the purposes of writing a dissertation and enrolling for additional modules. Unlike the HRDA, the EMA does not offer internships but the structure of the programme is similar in all other aspects to the HRDA. The aim of the EMA programme is to produce high-level professionals in the field of human rights and democratisation; it is increasingly adopting a more practical approach going beyond merely theoretical human rights education. Both HRDA and ERMA emphasise capacity-enhancement, the latter in particular in the post-conflict Balkan region in South East Europe. 
The ERMA is taught over three terms. The first term, which is from November to June, is delivered at the University of Sarajevo. The second term consists of a seven-week internship in the Balkan region while the third term, which is hosted by the University of Bologna in Italy, is devoted to dissertation writing. Similar to the HRDA, this programme responds to the developmental needs of a region through a practical, action-centred methodology. Both HRDA and ERMA programmes are interdisciplinary with a practical focus and EMA is offered as a multi-disciplinary programme that is now also incorporating a more practical focus.

\section{Partnership and degree structures}

There are also differences in the three programmes in terms of the degree and partnership structures. The HRDA is offered by one university, the University of Pretoria, which issues the degree without the insignia of the partner institutions (Centre for Human Rights), whereas the thirteen partner universities are responsible for delivery of the programme in the second semester. By comparison, the EMA's nine so-called 'inner-circle' universities confer a joint degree on all students participating in the programme. The ERMA programme is structured as a double degree conferred by two lead institutions, namely, centres affiliated to the universities of Bologna and Sarajevo.

\section{Student selection}

The three programmes also vary in terms of student selection criteria. All share academic merit as a central criterion and consider linguistic competency. In case of the HRDA, other factors, such as motivation, experience, gender balance, the inclusion of LGBTI persons and persons from indigenous and minority groups play a role in student selection. ${ }^{13}$ Another major factor which affects admission into the programme is the desideratum to ensure that as many African nationalities as possible are represented each year in the programme. The EMA includes experience and motivation in the selection criteria, whereas the ERMA does not evaluate other aspects (EIUC). In synopsis, the HRDA is the programme which has the broadest base of selection criteria and the only one which considers diversity and empowerment of vulnerable groups directly. Thirty to thirty-five students are selected for the HRDA (from among many hundreds of applications), EMA accepts about ninety students into its programme and ERMA thirty students per annum.

\section{Global campus}

The establishment of a Global Campus MoU in 2012, has decreased differences between the 
regional programmes. The Global Campus promotes a core curriculum that exhibits the following features: universal values, fundamental international and regional human rights instruments, the rights of women, children and minorities, promotion of democratisation and the rule of law, protection of victims of violence and conflicts, international criminal justice and the fight against impunity, significant interdisciplinary elements, experiential learning and operational skills building, including internships subject to availability, language training and similar standards of examinations and assessment of dissertations. Currently, the Global Campus focuses on strengthening the level of integration of the regional master's programmes and plans in the near future, from 2016 onwards. This will see the increased institutionalised exchanges of academics and students, the establishment of platforms to allow sharing of curricula and ideas, and organisation of joint training seminars, research activities and publications with the objective of educating a new generation of human rights professionals in an integrated global framework.

\section{Summary}

The above analysis revealed that the HRDA is indeed a programme which has been carefully designed to enhance capacity in Africa, in a specific field, namely, human-rights and democratisation. It is a unique programme and is regarded as 'the only course of its kind in Africa' (Centre for Human Rights). The comparison with similar programmes in Europe concluded that capacity-enhancement is a focus which is shared with ERMA, which is designed for a European post-conflict region, whereas this focus is not prevailing in the EMA which is taught in the context of a region with established democratic structures and human rights mechanisms.

The HRDA provides high quality training in human rights and democratisation. It has high impact, almost all the graduates are employed on the continent, in particular, in human rights and democracy institutions in their home countries or in regional and international organisations on the continent (MEDE 2003). ${ }^{14}$ The programme also produces a network of African human rights lawyers and academics.

\section{AFRICAN INTELLECTUAL MÉTISSAGE THROUGH THE HRDA}

A candidate who successfully completes the Master's Programme in Human Rights and Democratisation in Africa is a potential scholar who, in our opinion, has experienced the transmuting alchemy of African intellectual métissage for the following reasons: 


\section{Selection criteria and objectives}

The balanced selection and admission criteria to the HRDA and the objectives of the programme reflect the principles of African intellectual métissage. The first objective of the LL.M programme, which is stated as 'to train human rights experts who can be employed in government ministries, other national, international and regional bodies concerned with human rights and democracy' (CHR), assists in ensuring effectiveness of these bodies through imparting professionalism and operational competence. The end result is the transfer of technical skills and strengthening of the capacity of these organisations with the goal of improving the protection and promotion of human rights and democratisation in Africa. The second objective, which is in keeping with our use of African intellectual metissage, is articulated as to expand collaboration among African universities. Collaboration should result in a network of lawyers and academics, specialised in human rights and democracy. The programme envisages research and teaching that address the particular needs of Africa. Some identified needs include conflict prevention, democratic transition, strengthening of civil society, institutional building and the rule of law.

\section{Structure of the syllabus}

The syllabus, which is delivered in two semesters, covers a wide spectrum of human rights and democracy issues. It is important to note from the perspective of African intellectual metissage that most of the modules are taught against the backdrop of human rights and democracy norms in the UN and Africa generally. The regional systems of Europe, Inter-America and others offer useful contrasting and comparative tools. The well-acclaimed South African human rights edifice, anchored in an entrenched Bill of Rights, is singled out as a paradigm due to its elaborate human rights provisions in a comparatively new constitution, as well as the progressive human rights jurisprudence spawned by the South African courts.

\section{Profile and background of the module experts}

The background and profile of the module lecturers is yet another factor which truly demonstrates the pursuit of African intellectual metissage as one of the core aims of the programme. Module lecturers come from all over the world and include lecturers drawn from partnership universities.

\section{EVALUATION OF THE IMPACT OF THE MASTER'S IN HUMAN RIGHTS AND DEMOCRATISATION IN AFRICA (HRDA)}

We shall now proceed to evaluate whether the HRDA is indeed fulfilling its aspiration to train 
human rights experts who would contribute to the promotion of human rights and democratisation on the African continent. To obtain this perspective, we analysed alumni information from the programme's own database, ${ }^{15}$ and conducted a survey among the alumni to gain an understanding of the impact of the programme on opportunities, employability and skills development.

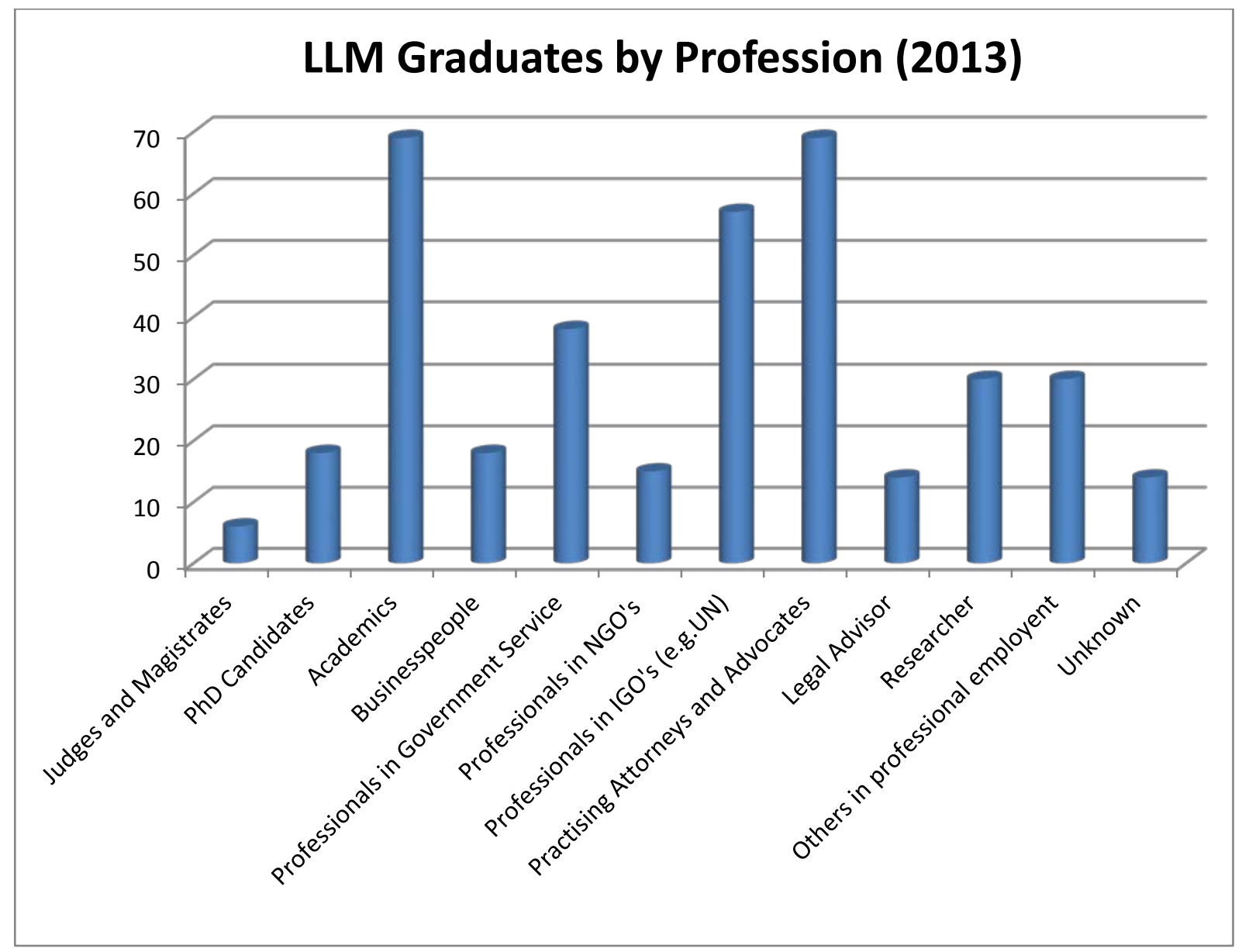

Figure 1: Employability and skills development of HRDA graduates

An analysis of the data reveals the extremely high employability rates of graduates: On $1^{\text {st }}$ July 2013, 96.83 per cent of the programmes' graduates were employed, exclusive of those who graduated in December 2012. The majority were holding leadership positions in key government, intergovernmental and human rights organisations. This data, obtained from the programme's alumni database, indicate that an overwhelming majority of alumni work in their home country.

\section{Voices of alumni}

We obtained information from alumni of the programme directly through a questionnaire 
administered by email to a sample; in addition, we evaluated information from the programme alumni association's newsletter 'Righting Wrongs'. The majority of respondents to the email questionnaire were of the view that the programme responds to a skills gap in their respective home countries and assists in resolving post-conflict issues. They indicated that they could not have acquired the same skills in their home country. When asked whether the qualification contributed to developing skills relevant to their present work and national environment, most candidates answered affirmatively. Many of the respondents indicated that, owing to lack of human resource capacity in their own countries, they could not have enjoyed a similar education locally.

Ismeme Zarifis, a 2009 graduate from Uganda, who now works as a technical advisor to the Ministry of Justice and Constitutional Affairs in Uganda commented on the programme's impact as follows:

... the HRDA was clearly not just a top quality graduate degree and educational experience, but represents a platform for realizing our full potential as human rights advocates in the region and internationally. The HRDA programme's emphasis on inter- and intro-regional exchange, has cultivated a corps of advocates and academics that are not only acting within their national borders, but are building on common goals and interests to act strategically and regionally (University of Pretoria Alumni Association 2011b).

Alumna Thabitha Sandra, an alumna from Kenya who graduated in 2012, emphasised the importance of transnational and cultural networking Other respondents to the alumni correspondence also echoed the sentiments that the degree afforded opportunities for cultural and academic exchanges.

Among the very few criticisms expressed by alumni was the following from Ernest Yaw Akko, an alumnus from Ghana who graduated in 2010:

Reality dawns on would-be graduates. Some resigned from their jobs to take up the course; others were fresh from school, with only a few people with jobs waiting for them. Where is the plethora of job and internship opportunities, many kept asking? For some, the default plan was to go home into private legal practice or to non-human rights jobs, and do little or nothing with their human rights knowledge (University of Pretoria Alumni Association 2011a).

Overall, the programme is rated highly and its impact has been noticeable. It is apparent that the LLM alumni have contributed significantly to greater awareness and knowledge of the African Human Rights system. ${ }^{16}$ It is the amalgamation of theoretical and practical knowledge gained during their studies, and participation in the extensive networks of contacts on the continent which have benefited the alumni greatly. 


\section{CONCLUDING REMARKS}

The theoretical analysis has revealed the critical role higher education plays in Africa as a driver of change and transformation in the distribution of knowledge, contributing to social and economic enhancement through capacity-enhancement. Greater awareness of the role of higher education in Africa's development and recognition of knowledge and innovation as essential drivers of socio-economic development needs are necessary. Higher education has to reinforce its role as a leading agent for transformation in Africa's developing context. To achieve this, a strong focus on capacity-enhancement and the intertwined processes of Africanisation and internationalisation are seminal. Internationalisation in Africa should be catalysed to reflect the unique identity of the continent and its universities, based on rich indigenous knowledge and cultural heritage.

African higher education must be a driver of change and transformation in the distribution of knowledge, contributing to social and economic enhancement both as a player and an agent in Africa. We argue that educators for the continent are best trained in Africa, and that all African states should collaborate to develop the next generation of professionals, technocrats and intellectuals who are capacitated to solve the continent's challenges. Ultimately, Africa could meet many of its skills needs through strengthening African intellectual métissage and specifically capacity-enhancement through its higher education system. Overall, higher education in Africa should be developed to become a regionally articulated system which allows for the mobility of students and cross-fruition due to the interaction among African universities in the course of their degree programmes. African intellectual métissage provides critical support for deliberative engagement, recognition of otherness and citizenship in its broadest sense. The present transformation and de-colonisation debate in South African higher education highlights the importance of endogenously driven transformation processes. African intellectual métissage should be infused in the ongoing South African higher education transformation debate, and could inspire similar processes in other post-colonial contexts.

Many important aspects of capacity-enhancement in Africa are entrenched in the1997 SADC Protocol. Greater awareness of the Protocol needs to be created and made operational. While the Protocol creates a viable framework for Southern Africa, its regional focus should be widened to include the entire African continent.

The evaluation of the HRDA has confirmed the tremendous contribution of academic programmes designed for Africa to build capacity. HRDA enshrines the principles of African intellectual métissage and has a significant impact on capacity-enhancement in human rights and democratisation, an area which is critical for achieving sustainable development in Africa. 
HRDA is a good example of the principles we have expounded and are advocating: an amalgam of internationalisation, capacity-enhancement and African intellectual metissage. This case study shows a very successful programme that could be reproduced. The programme's alumni assist in strengthening the development of a democratic culture based on human rights throughout the African continent.

It is also our view that the programme requires further strengthening and needs to develop as African and global realities change and the processes of Africanisation and internationalisation evolve. Given the magnitude of the task of developing democratic governance structures in Africa and finding appropriate responses to highly sensitive human rights issues, such as perceived conflicts between individual and collective human rights, as exemplified by clashes between the right to cultural integrity and individual rights in some countries, it is critical that capacity is developed in this field amongst young African intellectuals.

Co-badging of the degree by the various participating universities could further improve the structure of the programme and emphasise that it is a collective university effort across the continent. Furthermore, the programme could increase its impact if it were to admit a larger number of students. We also recommend that the HRDA includes a stronger African languages element.

\section{NOTES}

1. This French noun is originally translated as 'mix' (Collins web dictionary, http://www.collins dictionary.com/dictionary/french-english/m\%C3\%A9tissage (accessed 3 March 2015)). It refers to the notions of cross-fertilisation and cross-breeding and can also be understood to denote a converging point (in the sense of carrefour). It is frequently used in the context of cultural metissage (e.g. Ricardo Vieira 2014) 'Life Stories, Cultural Métissage, and Personal Identities', http://sgo.sagepub.com/content/4/1/2158244013517241.full-text.pdf+html (accessed 4 March 2014).

2. The founding architects of Negritude were the so-called les trois peres, Aime Cesaire from Martinique, Leopold Senghor, and Leon Damas of French Guiana (Gayana). See Negritude Essay at http://www.enotes.com/topics/negritude (accessed 1 December 2014).

3. For example, University of the Witwatersrand (http://www.wits.ac.za/prospective/ international/ 11395/financial_information.html (accessed 3 March 2015)), University of Cape Town (https://www.uct.ac.za/apply/intlapplicants/degree/fees/international/ (accessed 3 March 2014)) and University of the Free State (http://supportservices.ufs.ac.za/ content.aspx?id=119 (accessed 3 March 2015)) charge international fees for non-SADC students.

4. This article uses the programme's own abbreviation which is 'HRDA', the EU study abbreviates it as 'LLMA'.

5. www.chr.up.ac.za/indexphp/llm-h

6. The partner institutions are listed in section 5.3 below. Besides the University of Venda, the only other partner university from South Africa is the University of the Western Cape.

7. For example, the EU study on the master's programmes in human rights. 
8. The information was extrapolated from the programme alumni association's newsletter 'Righting Wrongs'; published by the University of Pretoria Alumni Association of the LLM programme in Human Rights and Democratisation in Africa, the Centre for Human Rights and the Faculty of Law, University of Pretoria.

9. A copy of the Memorandum of Understanding establishing the Global Campus is available at http://www.eiuc.org/education/global-campus-regional-masters/memorandum.html (accessed 3 March 2015). Art 2 of the MoU states: 'The aim of the GC is to educate a new generation of human rights professionals in a global and integrated global framework, who are able to meet global challenges which are informed by universal values and standards, European human rights policies and regional approaches to human rights, and aimed at strengthening the resilience of democracies and democratic movements on all continents.'

10. Document on file with authors.

11. Another evaluation of two Masters programmes, the HRDA in Africa and a LLM offered in Malta, was conducted in 2003.The evaluation was conducted by MEDE European Consultancy in partnership with Netherlands Humanist Committee on Human Rights and the Danish Institute for Human Rights (2003) under the title 'Evaluations of projects EIDHR: Human Rights Masters Programmes' at 6. This study concluded the quality and content of the teaching of the African and Mediterranean (Malta) Programmes to be `high-level, rewarding and demanding’ at 3, 4, 6.

12. 'Evaluations of projects EIDHR: Human Rights Masters Programmes'; the study concluded the quality and content of the teaching of the African and Mediterranean to be 'high-level, rewarding and demanding' 3, 4, 6.

13. Master's (Human Rights and Democratisation in Africa): Criteria for selection (copy on file with authors).

14. The study concluded the quality and content of the teaching of the African and Mediterranean to be 'high-level, rewarding and demanding' (at p 23).

15. The data was made available by the Centre for Human Rights at the University of Pretoria

16. Internal document Centre for Human Rights (NGO Prize nomination 2012).

\section{REFERENCES}

African Union. 2007. Addis Ababa Declaration on Science and Technology. http://www.oecd.org/ swac/publications/38769082.pdf (accessed 20 November 2016).

African Union. 2011. Establishment of the Pan African University: Project document. https://dilemmaxdotnet.files.wordpress.com/2013/02/afrian-union-establishment-of-the-panafrican-university-march-2011.pdf (accessed 20 November 2016).

Centre for Human Rights. University of Pretoria (CHE). Master's degree (LLM/Mphil) in Human Rights and Democratization in Africa. http://www.chr.up.ac.za/ index.php/llm-hrda.html (accessed 20 November 2016).

Cross, M. and S. Rouhani. 2004. Vanishing borders and new boundaries: Student and staff mobility and the internationalisation of South African higher education. African Universities in the twenty-first century 1: 234-249.

EIUS see European Inter-University Centre for Human Rights.

European Inter-University Centre for Human Rights. https://www.eiuc.org/ (accessed 20 November 2016).

Global Dialogue hosted by the International Education Association of South Africa participants. 2014. Nelson Mandela Bay Global Dialogue Declaration on the Future of internationalisation of higher education. $\quad$ http://obiret-iesalc.udg.mx/sites/default/files/adjuntos/nelson-mandela-baydeclaration-2014-cbie.pdf (accessed 25 November 2016).

Hagenmeier, Cornelius C. A. 2015. Ensuring equality in higher education partnerships involving unequal universities in divergent contexts. In Higher education partnerships for the future, ed. 
Nico Jooste, Hans de Wit and Savo Heleta. Nelson Mandela Metropolitan University, Unit for Higher Education Internationalisation in the Developing World. An abridged version is published in 83 International Higher Education (2015) 9.

Heyns, C. 2006. Regional master's programmes in Africa: Case studies and analysis. Journal of Educational Studies 5(2): 213-245.

Jooste, N. 2012. Prologue. In Internationalisation of higher education: Benchmarking across borders. Colloquium Series. Nelson Mandela Metropolitan University, Port Elizabeth, South Africa, Volume 5.

Jowi, J. O., J. Knight and C. Sehoole. 2013. Internationalisation of African Higher Education. In Internationalisation of African Higher Education, 11-31. Sense Publishers.

Knight, J. 2004. Internationalization remodelled: Definition, approaches, and rationales. Journal of Studies in International Education 8(1): 5-31.

Lansink, A. 2004. The African university: Contestations in the production of knowledge and identity. In Towards an African identity of higher education, 121-144. Vista University and Skotaville Media, Pretoria.

Lebakeng, T. 2004. Towards a relevant higher education epistemology. In Towards an African identity of higher education, 109-119. Vista University and Skotaville Media, Pretoria.

Lumumba, N. T. 2008. Higher Education as an African public sphere and the university as a site of resistance and claim of ownership for the National Project. CODESRIA, Yaoundé.

Makgoba, M. and S. Seepe. 2004. Knowledge and identity: An African vision of higher education transformation. In Towards an African identity of higher education, 13-58. Vista University and Skotaville Media, Pretoria.

MEDE European Consultancy. 2003. Final Report: Evaluation of the African LLM based at the Human Rights Centre, University of Pretoria, and the Mediterranean Master on Human Rights based at the University of Malta. https://ec.europa.eu/europeaid/sites/devco/files/study-evaluation-humanrights-masters-south-africa-200311_en_1.pdf (accessed 2 July 2016).

NEPAD. 2009. Annual Report Education and Training. http://www.nepad.org/system/files/NEW_ NEPAD_AR_LR_FINAL_ENGLISH.pdf (accessed 23 April 2014).

Nkrumah, K. 1963. Africa must unite. Heinemann Educational Books.

Nkrumah, K. 1964. Consciencism: Philosophy and ideology for de-colonisation. Revised edition copyright 1970, 2009. Monthly Review Press, New York.

Nkrumah, K. 1965. Neo colonialism: The last stage of imperialism. International Publishers.

OECD see Organization for Economic Co-operation and Development.

Organization for Economic Co-operation and Development. 1996. Internationalising the Curriculum in Higher Education. Paris, OECD.

Olukoshi, A. and P. T. Zeleza. 2004. In The struggle for African universities and knowledge, ed. P. T. Zeleza and A. Olukoshi.

Ramose, M. B. 1999. African philosophy through ubuntu. Human Rights Network.

SADC see South African Development Community.

Southern African Development Community. 1997. Protocol on Education and Training. http://www. sadc.int/files/3813/5292/8362/Protocol_on_Education_Training1997.pdf_ (accessed 20 November 2016).

University of Cape Town. https://www.uct.ac.za/apply/intlapplicants/degree/fees/international.html (accessed 3 March 2015).

University of Free State. http://supportservice.ufs.ac.za/content.aspx?=119.html (accessed 3 March 2015).

University of the Witwatersrand. http://www.wits.ac.za/prospective/international/11395/financial_ information.html (accessed 3 March 2015). 
University of Pretoria Alumni Association. 2011a. Alumni newsletter 'Righting Wrongs' Issue No. 1 2011.

University of Pretoria: Alumni Association. 2011b. Alumni newsletter 'Righting Wrongs' Issue No. 3 2011.

University of Pretoria: Alumni Association. 2012. Alumni newsletter 'Righting Wrongs' Issue No. 5 2012.

Vieira, R. 2014. Life stories, cultural métissage, and personal identities. SAGE Open 4(1): 2158244013517241.

Visser, H. and C. Heyns. (Ed.). 2007. 'Transformation and the Faculty of Law of the University of Pretoria'. PULP.

World Bank. 1999. Education Sector Strategy. http://siteresources.worldbank.org/EDUCATION/ Resources/ESSU/education_strategy_1999.pdf (accessed 2 July 2016).

World Conference on Higher Education. 1998. World Declaration on Higher Education for the TwentyFirst Century. Available at: http://unesdoc.unesco.org/images/0011/001163/116345e.pdf (accessed 10 September, 2014).

World Health Organization. 2013. WHO Country cooperation strategy at a glance. Belize.

Yesufu, T. M. 1973. Creating the African university: Emerging issues in the 1970's. Published for the Association of African Universities by Oxford University Press. 